\title{
Surface mapping, structural modelling and kinematics along the sinistral strike-slip fault zone, NE Potwar, Pakistan
}

\author{
Muhammad Nouman $^{1} \cdot$ Gohar Rehman $^{2} \cdot$ Muhammad Yaseen $^{3}(1) \cdot$ Sohail Wahid $^{1} \cdot$ Ibrahim Safi $^{1} \cdot$ Jawad Ahmad $^{3}$. \\ Duong Van $\mathrm{Hao}^{4}$
}

Received: 19 May 2021 / Accepted: 30 October 2021 / Published online: 26 November 2021

(c) The Author(s) 2021

\begin{abstract}
This research was carried out to understand the nature of strike-slip Jhelum Fault zone and to propose a model for the surface to subsurface deformation pattern. Field data along with satellite images are used to construct the geological map. Moreover, the subsurface model has been proposed using the mechanism of dip-isogons in computer application which connects points of equal inclination or dip on the outer and inner bounding surfaces of a folded layers. The proposed geological map and subsurface model shows that the Jhelum Fault when propagated in the south from Hazara-Kashmir Syntaxis forms a continuous shear zone on surface with some discontinuous exposure of splay faults rather than exposed as continuous discrete break. Likewise, the subsurface cross sections show that deformation along the fault zone is accumulated by splay faults from the main Jhelum Fault, which forms a positive flower structure with steep north-eastward dips, which is characteristics of strike-slip movement along Jhelum Fault Zone. The vertical stratigraphic throw along these faults shows small offsets and little east-west shortening, indicating that the major slip along the fault is strike slip.
\end{abstract}

Keywords Tectonics $\cdot$ Structure modelling $\cdot$ Kinematics $\cdot$ Jhelum Fault zone $\cdot$ Pakistan

\section{Introduction}

Tectonically, the study area is part of the Sub-Himalayas of North Pakistan which covers a part of north-eastern Potwar Plateau and some portion of Kotli District, Azad Jammu and Kashmir (AJK) in the north of Mangla Dam (Fig. 1 a, b). Geographically the area lies between $33^{\circ} 30^{\prime} 00^{\prime \prime}$ and $33^{\circ} 43^{\prime} 30^{\prime \prime} \mathrm{N} ; 73^{\circ} 30^{\prime} 55^{\prime \prime}$ to $73^{\circ} 42^{\prime} 00^{\prime \prime} \mathrm{E}$. Stratigraphically rocks of Miocene to Recent age are exposed where the oldest rock units are Murree and Kamlial Formations of Rawalpindi Group (early to middle Miocene), overlain by Siwalik Group rocks (middle Miocene

Muhammad Yaseen

yaseengeo@awkum.edu.pk

1 National Centre of Excellence in Geology, University of Peshawar, Peshawar, Pakistan

2 Department of Geology, University of Peshawar, Peshawar, Pakistan

3 Department of Geology, Abdul Wali Khan University Mardan, Mardan, Khyber Pakhtunkhwa, Pakistan

4 Department of Geophysics, Hanoi University of Mining and Geology, Hanoi, Vietnam to early Pleistocene) and unconsolidated stream deposits of Holocene (Ahmad et al. 2004). Jhelum Fault is one of the strike-slip faults among them, having sinistral sense of slip, starting from the western limb of Hazara-Kashmir Syntaxis (HKS) and running southward up to eastern Salt Range (Yaseen et al. 2021a; Baig et al. 2010) (Fig. 1). Baig and Lawrence in 1987 explained the Jhelum Fault as a left-lateral strike-slip fault with reverse ramp, along which the fresh water Miocene strata, i.e. Rawalpindi Group, and Pre-Cambrian meta-sediments, i.e. Abbottabad and Hazara Formations, are intensely distorted in the terrain inbetween Balakot and Muzaffarabad localities. The Jhelum Fault drags the Panjal Volcanics and Triassic limestone southward, along an offset of $38 \mathrm{~km}$ (Baig and Lawrence 1987). Mehdi (2005) in the light of seismicity record of HKS in northern Pakistan pointed the Jhelum Fault and stated that it is one of the active faults in Pakistan. Tapponnier et al. (2006) further explained that being recent and active structure the geomorphic expression on satellite image clearly depicts that it cuts several tributaries feeding the Jhelum River at its western bank, along $50 \mathrm{~km}$ North-South-directed surface trace. At an advance structural level, the Jhelum Fault shows the evidence of thrust

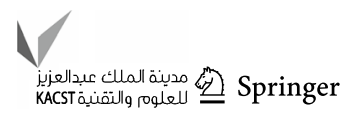


Fig. 1 a Showing the Tectonic map of North Pakistan, exhibiting the major structural elements and study area (from Kazmi and Rana, 1982) b

Tectono-structural map of IndoEurasian collisional zone showing major structural boundaries (from Gaetani et al. 1996 and Zanchi et al. 2000) c Map showing the structural elements of Pakistatn, Afghan Block, Indian Shield and Arabia Sea (from Kazmi and Rana, 1982)

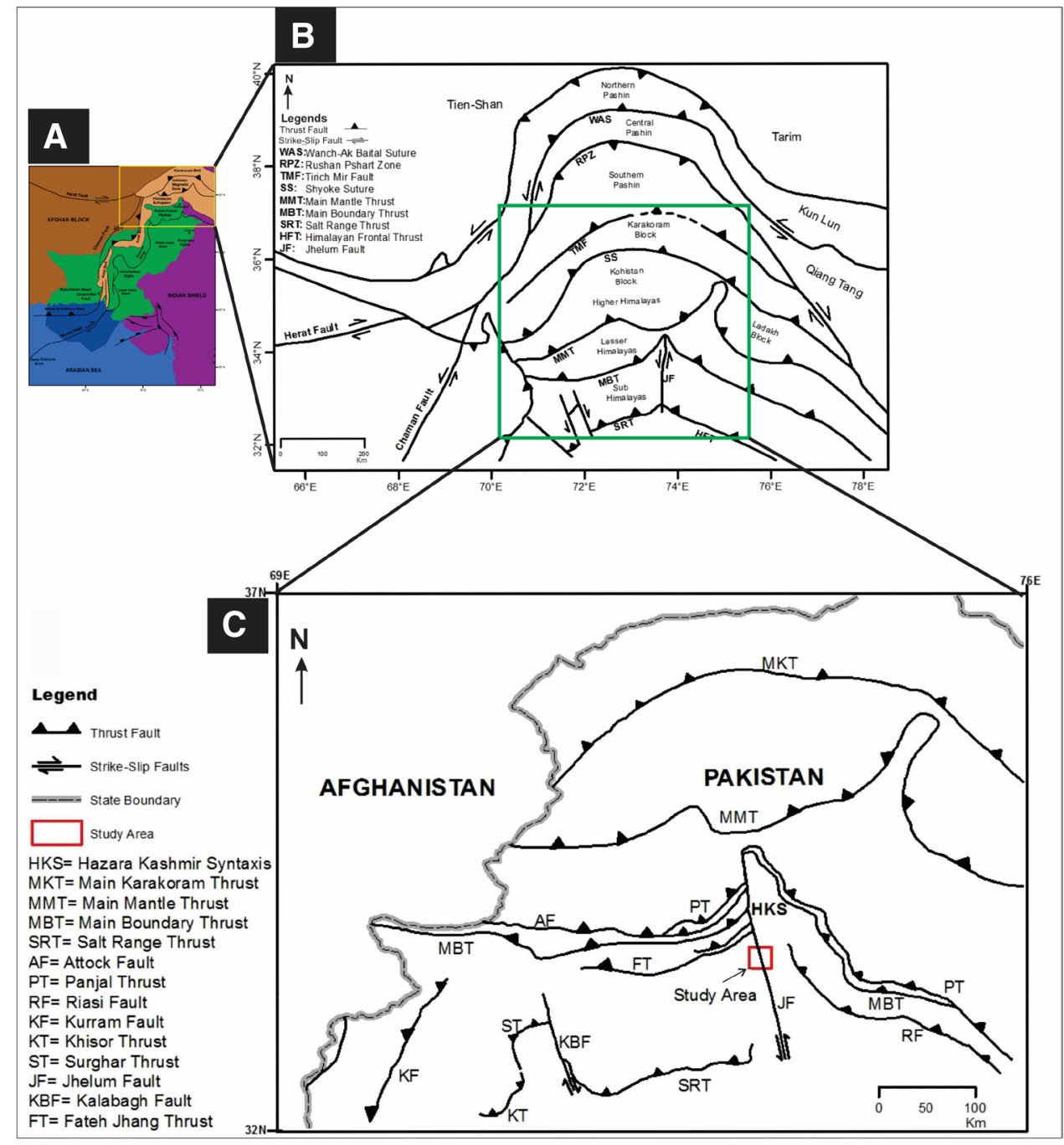

movement and back steepening; That is, the fault plane of Jhelum Fault changes its dip direction from SE in southern portion to NE in northern portion (Baig et al. 2008). Kazmi and Rana in (1982) mapped the Jhelum Fault along the Jhelum River from HKS in north and terminated it on the eastern Salt Range, and this was then accepted and used in many researches. Ahmad et al. (2004) mapped the proposed research area at 1:50,000 scale. According to their map, the Jhelum Fault is not exposed at surface in the research area. So in this research the study area along Jhelum River is keenly investigated to clarify the surface exposure and nature of Jhelum Fault zone. The aim of this research was to explore the probable existence of Jhelum Fault and surface to subsurface modelling with detailed structural mapping of the area at 1:25,000 scale, to understand nature and behaviour of Jhelum Fault zone with 3D structural modelling as previously done by Ghani et al. 2018 in the case of Kohat Fold and thrust belt. Investigation of the structural deformation through modelling techniques was proposed. This research provides the updated geological map of the Potwar Plateau.

\section{Geological setting}

Anticlockwise rotation of Indian Plate after the head-on collision with Eurasian plate results in the development of peculiar curves in the Himalayan fold and thrust belt, leading to genesis of several major strike-slip faults in Pakistan (Shah 2009). Several Gondwanian micro-continents and also some Island Arcs are involved in Himalayan collisional zone (Dietrich et al. 1983 and Searle 1991), where the northward drift of the Gondwanian fragments initiated in early Jurassic period. The Hindu Kush and Karakoram Blocks were the first to collide with Eurasian Plate, respectively, followed by the Afghan Block and lastly the Kohistan Island Arc (KIA) LeFort 1975; Windley 1983). The collision of Hindu Kush shield rocks with the southern boundary of 
Eurasian Plate occurs in late Triassic Period (211-201 Ma), shortly followed by the collision of the Karakoram Block in early Jurassic Period (189-184 Ma). At the time when the Hindu Kush and Karakoram Block was moving northward and striking the Eurasian Plate, magmatic activity in the Paleo-Tethys leads to the development of Kohistan Island Arc (KIA). Further northward drift of plates leads to the impingement of KIA with Karakoram Block during late Cretaceous (86-72 Ma); finally, this collisional process ended when the Indian Plate collided with Eurasian Plate along the southern margin of KIA during the late Oligocene to early Miocene (28-23 Ma). The Himalayan collision leads to the development of several major faults, which are of great significance in describing the orogeny of Himalayan Ranges (Zanchi and Gaetani, 2011; Angiolini et al. 2013) (Fig. 1 a, b, c).

The several major faults/suture that resulted from the plates collisions are the Rushan-Pshart Suture (RPS) between Central Pamir of Eurasian terrain in north and Southern Pamir-Hindu Kush in south. The Tirich Mir Boundary Zone (TMBZ) where the Pamir-Hindu Kush Block is riding above the Karakoram Block. The Main Karakoram Thrust (MKT), along which the Karakoram Block is obducted over the KIA. The Main Mantle Thrust/ Indus Suture Zone (MMT/ISZ), along this fault the KIA in north is thrusted over the Indian Plate in the south (Zanchi and Gaetani, 2011; Angiolini et al. 2013) (Fig. 1 b). The ongoing convergence in the north of Pakistan leads to development of many other regional scale geological structures in the India Plate, i.e. Main Central Thrust (MCT), Main Boundary Thrust (MBT), Main Frontal Thrust/Salt Range Thrust (MFT/SRT) (Grelaud et al. 2002). The age of MCT is about $20 \mathrm{Ma}$, whereas it is not well developed in Pakistan (north-western Himalayas); here, it has lateral westward continuation, i.e. Panjal/Khairabad Fault, and the age of MBT is estimated about $10 \mathrm{Ma}$. These regional thrusts divide the Himalayan Orogeny in three zones, i.e. Higher Himalayas (MMT in the north and MCT in the south), Lesser Himalaya (MCT in the north and MBT in the south) and Sub-Himalayas (MBT in north and SRT/HMF in south) (Trelaor et al. 1992 and Pogue et al. 1999; DiPietro and Pogue 2004) (Fig. 1 b). In Pakistan, the Sub-Himalaya comprises Kohat Plateau on the west and Potwar Plateau on the east.

\section{Materials and methods}

Field work to study area was carried out at different stages for understanding the stratigraphy, structural setup and topography of the area; furthermore, different field data were also collected, i.e. strike/dip measurement, contact marking, field photographs, etc. The field data measured and collected were then plotted on Google Earth Software and exported to a GIS Software to draw a surface geological map at 1:25,000 scale as followed by Yaseen et al. (2021a, b). Secondly, after constructing the geological map, the subsurface cross sections along four different traverses prepared using the Move 2013 software in order to build a possible subsurface model for structural deformation and subsurface stratigraphic distribution. While preparing the subsurface cross section, the stratigraphic control up to Miocene strata was maintain from surface outcrops, whereas the deeper and older stratigraphy was correlated from nearby well data, i.e. Kallar X-01 as recently done by Ishaq et al. 2020 similarly in a different basin.

\section{Stratigraphy}

The exposed stratigraphic succession ranges from Miocene to Recent. The oldest rock units exposed within the study area are Murree and Kamlial Formations of Rawalpindi Group (early to middle Miocene), overlain by Siwalik Group rocks (middle Miocene to early Pleistocene), and unconsolidated stream deposits of Holocene (Table 1).

\section{Murree Formation (early Miocene)}

This unit is consisting of uniform sequence of dark reddish and purple clay and greyish purple and greyish green sandstone (Fig. 2a). The lower part of this unit (Fateh Jhang member) is composed of calcitic, greenish grey sandstone and contains reworked fossils from Eocene strata. In the study area, the Murree Formation is exposed along the crest of two long, merging northward anticlines. Its upper contact is conformable (transitional) with the Kamlial Formation, whereas the lower contact was not exposed.

\section{Kamlial formation (middle-late Miocene)}

Compositionally, it consists of purplish grey to dark brick red, medium to coarse-grained sandstone. Also contains compact greyish purple shale horizons and yellowish to purple conglomerate (Fig. 2b). It also shows thinning in northeastern direction, from $600 \mathrm{~m}$ (in Western portion) to $350 \mathrm{~m}$ (in north-eastern portion). Both the upper and lower contacts are conformable, lower gradational with Murree and upper with Siwalik Group.

\section{Siwalik group}

\section{Chinji formation (late Miocene)}

Chinji Formation is mainly composed of reddish grey clays with subordinate horizons of ash grey to brownish grey

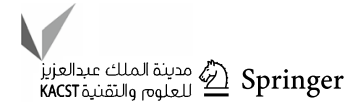


Table 1 Stratigraphic log of the exposed lithologies in the Study Area

\section{Stratigraphic log of the exposed lithologies in the Study Area.}

\begin{tabular}{|c|c|c|c|c|c|}
\hline \multicolumn{2}{|c|}{ Age } & \multirow{2}{*}{$\begin{array}{c}\text { Formation } \\
\begin{array}{c}\text { Soan } \\
\text { Formation }\end{array}\end{array}$} & \multirow{2}{*}{ 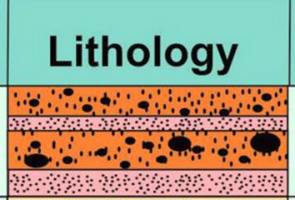 } & \multirow{2}{*}{$\begin{array}{c}\text { Thickness } \\
\text { (m) } \\
560\end{array}$} & \multirow{2}{*}{$\begin{array}{l}\text { Description } \\
\text { Brownish to reddish, thick massive } \\
\text { conglomerate and also contains beds of } \\
\text { muddy to reddish brown clay. }\end{array}$} \\
\hline Quat & $\begin{array}{l}\text { Lt. Pliocene- } \\
\text { E. Pliestocene }\end{array}$ & & & & \\
\hline \multirow{5}{*}{$\frac{\substack{\frac{\pi}{0} \\
\frac{\pi}{\pi}}}{10}$} & $\begin{array}{c}\text { Middle } \\
\text { Pliocene }\end{array}$ & $\begin{array}{l}\text { Dhok Pathan } \\
\text { Formation }\end{array}$ & \begin{tabular}{|lll}
$+\cdots$ \\
\hdashline
\end{tabular} & 916 & $\begin{array}{l}\text { Uniformly alternating sequence of muddy } \\
\text { to brownish gray sandstone and light gray } \\
\text { to dull reddish silty clay. } \\
\text { Sandstone } 40 \% \text { and clays } 60 \% \text {. }\end{array}$ \\
\hline & $\begin{array}{c}\text { Early } \\
\text { Pliocene }\end{array}$ & $\begin{array}{l}\text { Nagri } \\
\text { Formation }\end{array}$ & & 1330 & $\begin{array}{l}\text { Greenish gray, massive, medium to coarse } \\
\text { grained sandstone with subordinate } \\
\text { intercalations of reddish brown mudstone. }\end{array}$ \\
\hline & $\begin{array}{l}\text { Late } \\
\text { Miocene }\end{array}$ & $\begin{array}{l}\text { Chinji } \\
\text { Formation }\end{array}$ & 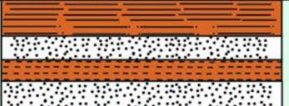 & $\begin{array}{r}1083-450 \\
\text { West-East }\end{array}$ & $\begin{array}{l}\text { Alternate beds of reddish brown claystone } \\
\text { and brownish gray, fine to medium grained } \\
\text { sandstone. }\end{array}$ \\
\hline & $\begin{array}{l}\text { Mid-Late } \\
\text { Miocene }\end{array}$ & $\begin{array}{c}\text { Kamlial } \\
\text { Formation }\end{array}$ & कीp & $\begin{array}{l}600-350 \\
\text { West-East }\end{array}$ & $\begin{array}{l}\text { Purple gray and dark red, medium to } \\
\text { coarse grained sandstone with } \\
\text { intercalations of mudstone and } \\
\text { conglomerate. }\end{array}$ \\
\hline & $\begin{array}{l}\text { Early } \\
\text { Miocene }\end{array}$ & $\begin{array}{l}\text { Murree } \\
\text { Formation }\end{array}$ & & 2500 & $\begin{array}{l}\text { Dark red to purple and reddish gray } \\
\text { sandstone and siltstone, purple to } \\
\text { reddish brown mudstone. }\end{array}$ \\
\hline
\end{tabular}

sandstone. The sandstone unit is fine- to medium-grained, cross-bedded and shows gritty texture (Fig. 3a). It is vastly spread over the Kohat-Potwar Province, whereas absent in the Lower Indus Basin except in the southern portion of eastern Sulaiman Range. In the studied area, the Chinji Formation topographically forms the valleys and low-lying discontinuous ridges. In the studied area, the thickness also shows thinning towards east, i.e. $1083 \mathrm{~m}$ (in west) and $450 \mathrm{~m}$ (east). Lower contact is conformable (sharp) with the Kamlial Formation of the Rawalpindi Group, and the upper contact is also conformable and sharp with the Nagri Formation, marked by the first thick greenish sandstone unit.

\section{Nagri formation (early pliocene)}

This stratigraphic unit is composed mainly of greenish grey sandstone. The sandstone is medium- to coarse-grained, massive, and at places shows "salt and pepper" pattern and cross-bedding (Fig. 3b). Occasionally also have dull red or brownish clayey horizons. In research area, topographically it forms continuous ridges and marked the maximum surface exposure in the study area. The thickness of this unit in the studied area is $1330 \mathrm{~m}$. The Nagri Formation conformably overlies Chinji Formation on Kohat-Potwar
Plateau, and the upper contact is gradational with the Dhok Pathan Formation.

\section{Dhok Pathan (middle pliocene)}

Compositionally it consists of uniformly alternating sequence of muddy to brownish grey sandstone and light grey to dull reddish clay (Fig. 4a). Topographically, it forms thin parallel ridges and valleys and at places is marked by the rugged topography, the Lower contact is transitional with Nagri, and upper contact is dis-conformable with the Soan Formation (Fig. 4).

\section{Soan Formation (late Pliocene to early Pleistocene)}

The Soan Formation is mainly composed of brownish to reddish, thick massive conglomerate and also beds of muddy to reddish brown clay or sandstone. The ratio of conglomerate to sandstone/clay beds varies (Fig. 4b). The pebble size sediments in the conglomerate are mainly limestone (grey-like Margalla Hill Formation), sandstone, quartzite, gneiss, etc. Lower contact is marked as disconformable with the Dhok Pathan Formation because of sudden coarsening of sediments. 
Fig. 2 North-west-looking view showing road side outcrop of purple-reddish sandstone bed of Murree Formation. b Northwest-looking view showing road side outcrop of Kamlial Formation, greyish sandstone with purplish shale in-between

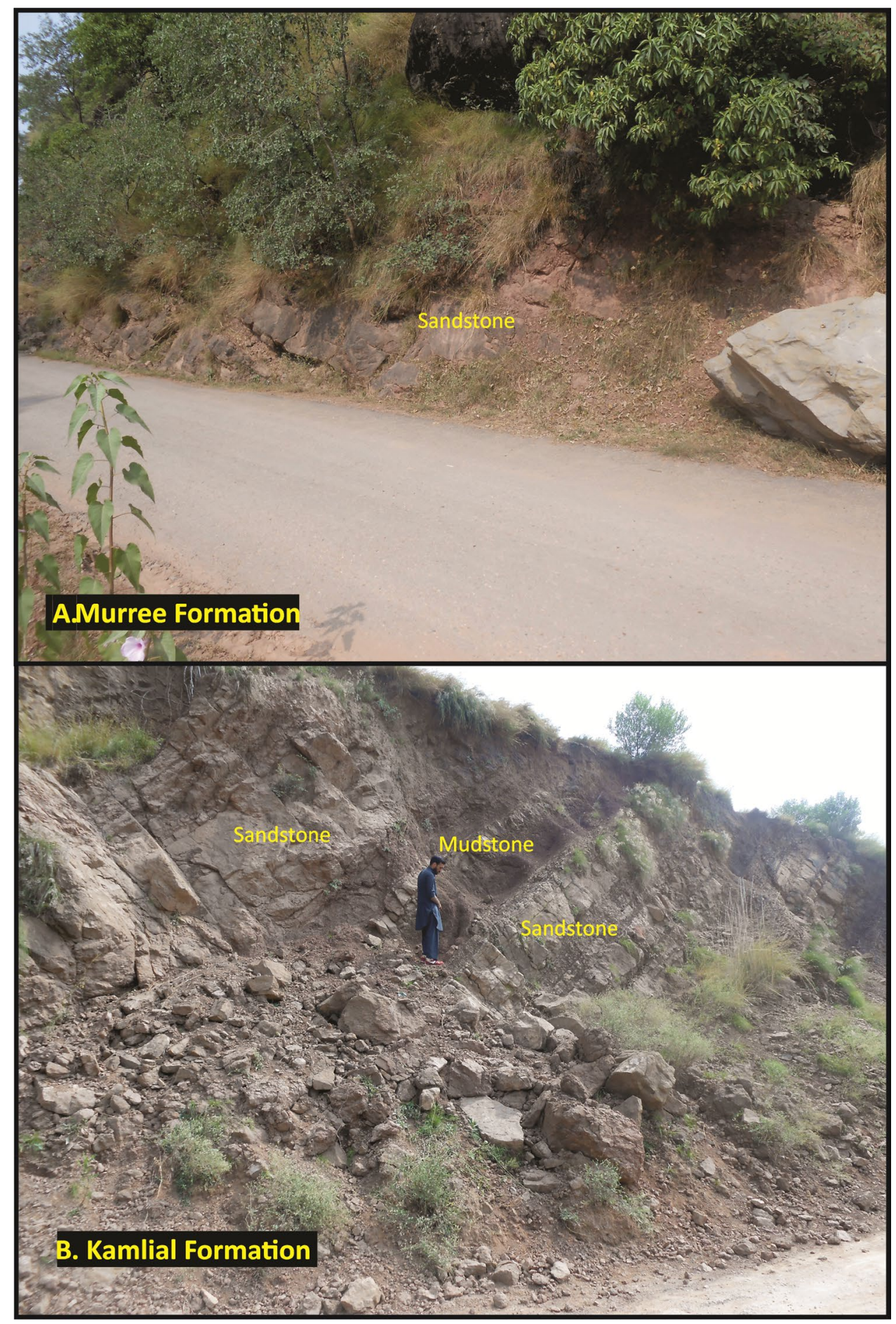

\section{Structural interpretation and modelling}

Following is the modus operandi for the structural interpretation and modelling;

1. Geological mapping

2. Structural transect and their restoration

\section{Geological mapping}

A surface geological map is prepared at scale 1:25,000, based on the integration of field data (i.e. strike/dip data, contacts), topography, previous maps and Google Earth image (Fig. 5). Based on the surface geological mapping, 
Fig. 3 a West-looking view showing an outcrop Chinji Formation with ash grey clays, and friable sandstone. b Southwest-looking view showing road side outcrop of massive grey Sandstone of Nagri Formation

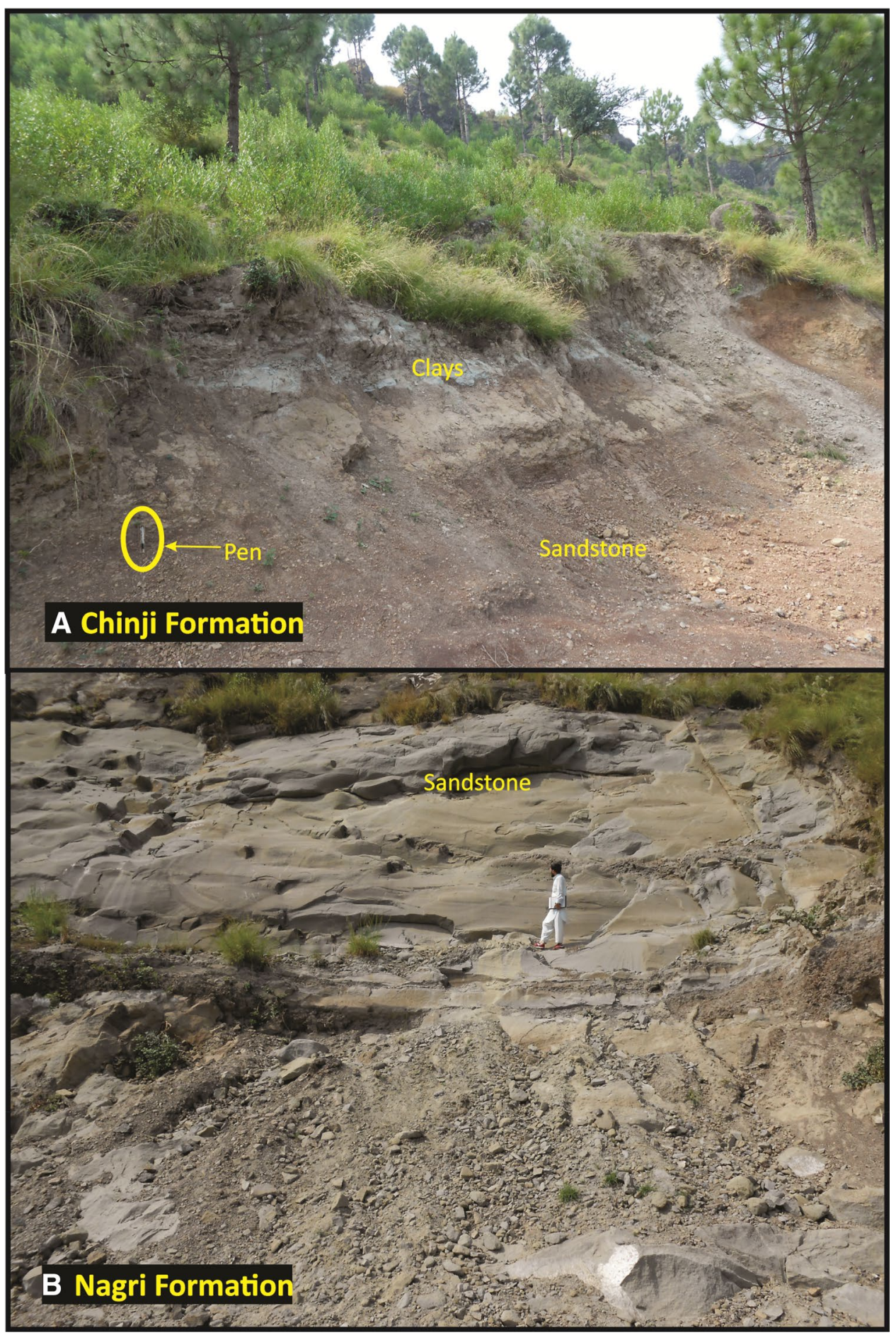

it is found that molasse sediments of the Siwalik Group with considerable exposures of the Rawalpindi Group predominantly cover the area. The Chinji Formation within in the area shows variable thickness, i.e. relatively thinner towards the eastern side. Topographically, the sandstone of the Kamlial and the Nagri Formations marks the high rising ridges with heights up to $1400 \mathrm{~m}$ (from sea level), whereas the other strata being comparatively less competent forms the low-lying narrow, discontinuous ridges and valleys, with rugged topography at places. While plotting the dip strike data and observing 
Fig. 4 a West-looking view showing road side outcrop of muddy sandstone bed of

Dhok Pathan Formation. b

East-looking road side view of brownish conglomerate of Soan

Formation

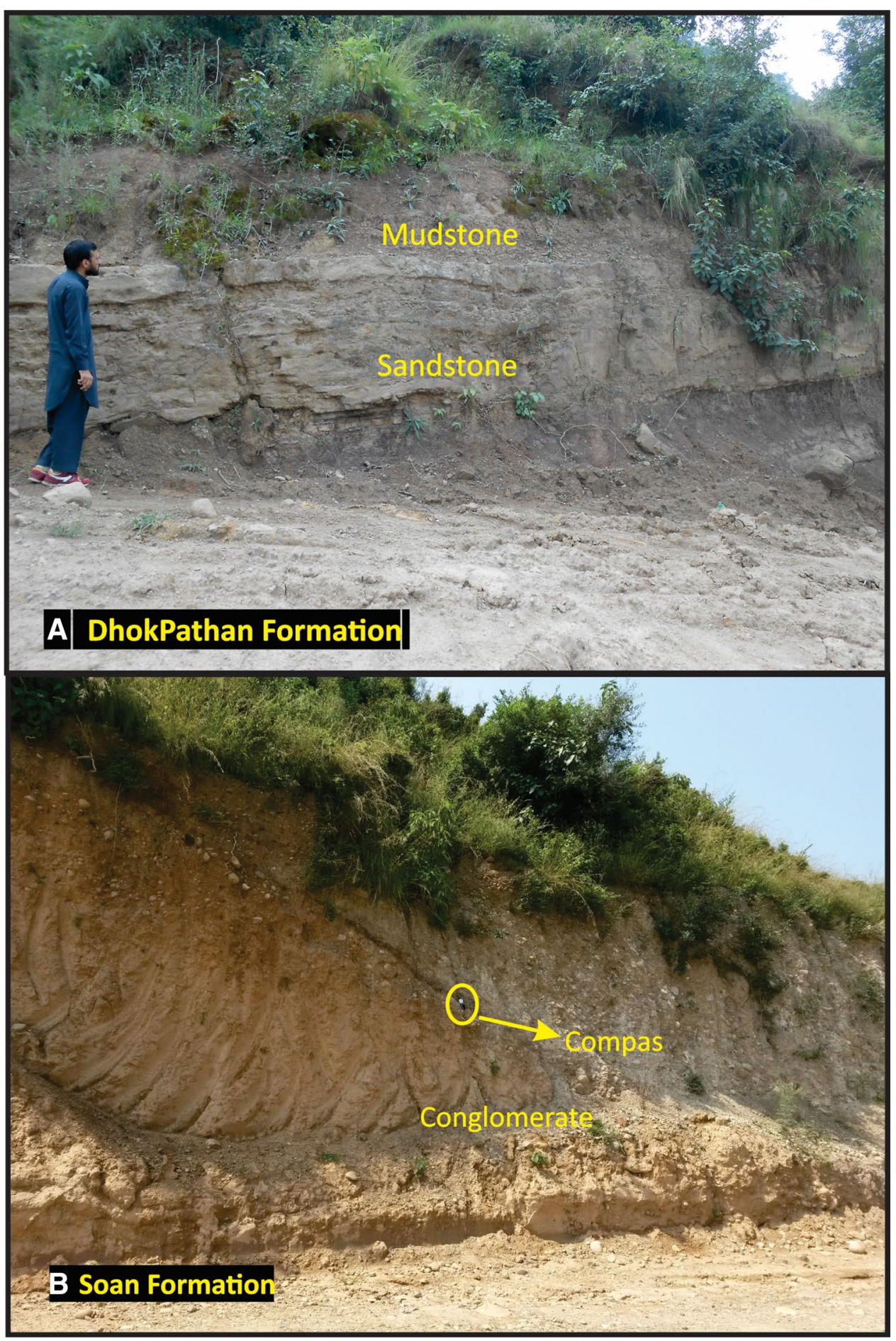

the structural deformation a great deal of heterogeneity is found in the trend of the strata, showing that the area is severely deformed along different stress directions, i.e. the two major stresses are roughly oriented in NW-SE and NE-SW directions leading to development of two different sets of folds as beforehand studied by few authors with similar approaches like Radwan et al, $2021 \mathrm{a}, \mathrm{b}$. 


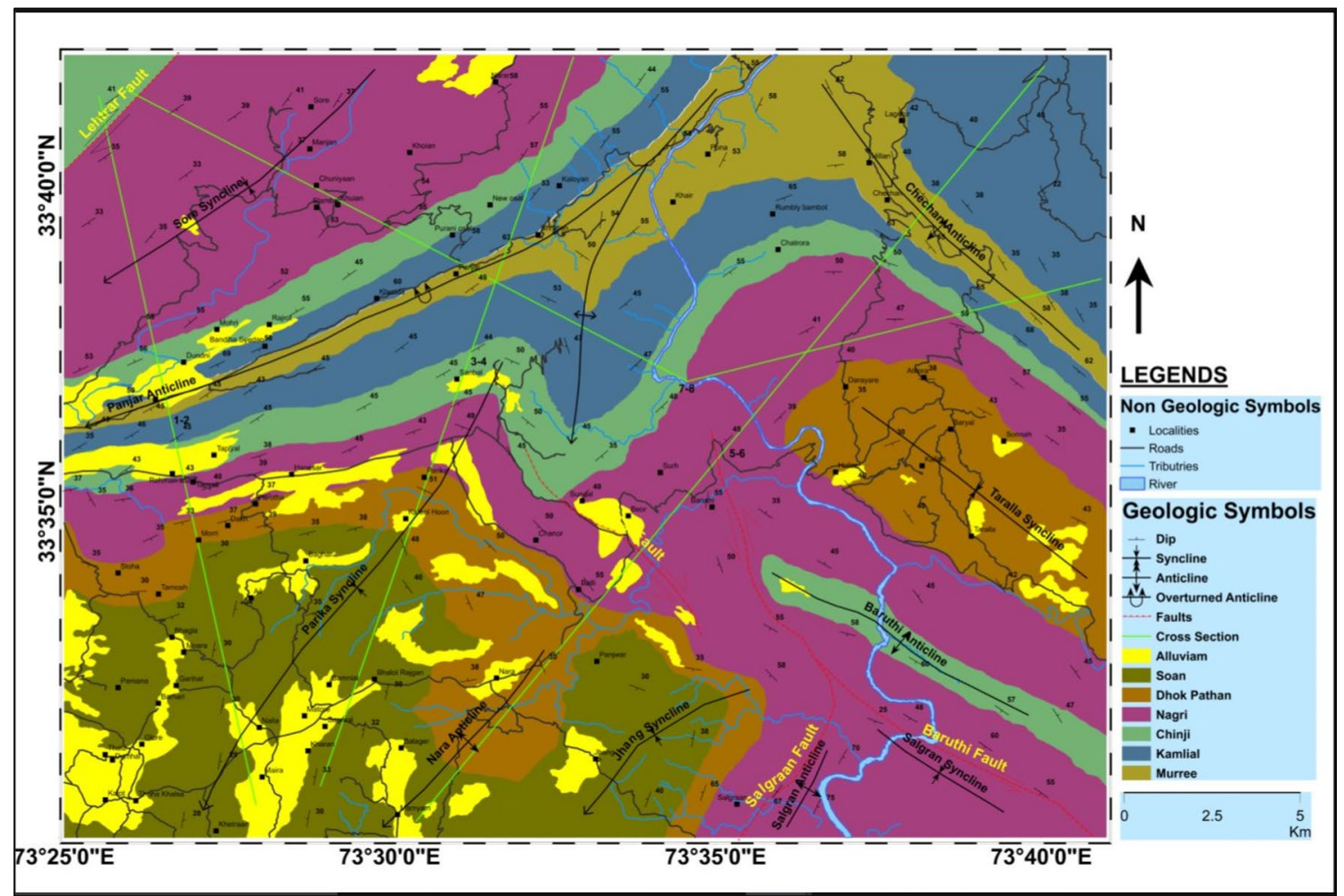

Fig. 5 Surface geological map of the Study Area, at 1:25,000 scale

\section{Fold Structures}

The area is structurally complex due to the overall north south shortening of Indian Plate and presence of strike-slip sense of shearing. Various folds marked are broadly categorized in two different trends, i.e. NE-SW and NW-SE. The NE-SW-trending folds cover the western of the area, whereas the NW-SE-trending folds develop in the eastern side of the mapped area.

\section{North-east-trending folds}

Starting from the NW corner of the study area, there is a huge syncline, i.e. "Sore Syncline". The Sore Syncline is an open fold with inter-limb angle $\sim 95^{\circ}$, with the Nagri Formation at its core. The hinge zone of the fold is plunging in the South-West direction. The northern limb of the Sore Syncline is dipping $\sim 35^{\circ}$ towards the southeast, whereas the southern limb is relatively steeper in the North-West direction. Moving south this open fold merges into a relatively tight and north verging anticline, i.e. "Panjar Anticline". The Panjar Anticline is the largest and complexly deformed structure in the area. It has the Murree Formation outcropping along its core and shares the northern limb with Sore Syncline with the NorthWest dip direction. This anticline shows overturned nature in northward direction along the Miocene strata, with both limbs dipping in South-East quadrant (here the northern limb is steeper than southern limb). While going up to younger strata, the overturned nature of the northern limb changes to normal dips of approximately $55^{\circ}$ North-West. The southern limb of Panjar Anticline is re-deformed in east west direction, in north of mapped area due to shearing along Jhelum Fault. The southern limb of this anticline merges with the western limb of the Taralla Syncline (i.e. NW trending) with a sharp southward twist in the strata. In south of Panjar Anticline, the deformation pattern and the trend of folds slightly change to the NNE and we have the Formation of the "Parika Syncline". The Parika Syncline is a South-West plunging syncline with the Soan Formation in its core. The western limb is dipping at $35 \mathrm{deg}$ towards south-east quadrant, and the eastward limb is dipping in the NorthWest direction $\left(\sim 40^{\circ}\right)$. Moving eastward following the eastern limb of Parika Syncline there is development of a counter anticline, i.e. the Nara Anticline. The Nara Anticline is also a South-West plunging gentle anticline with 


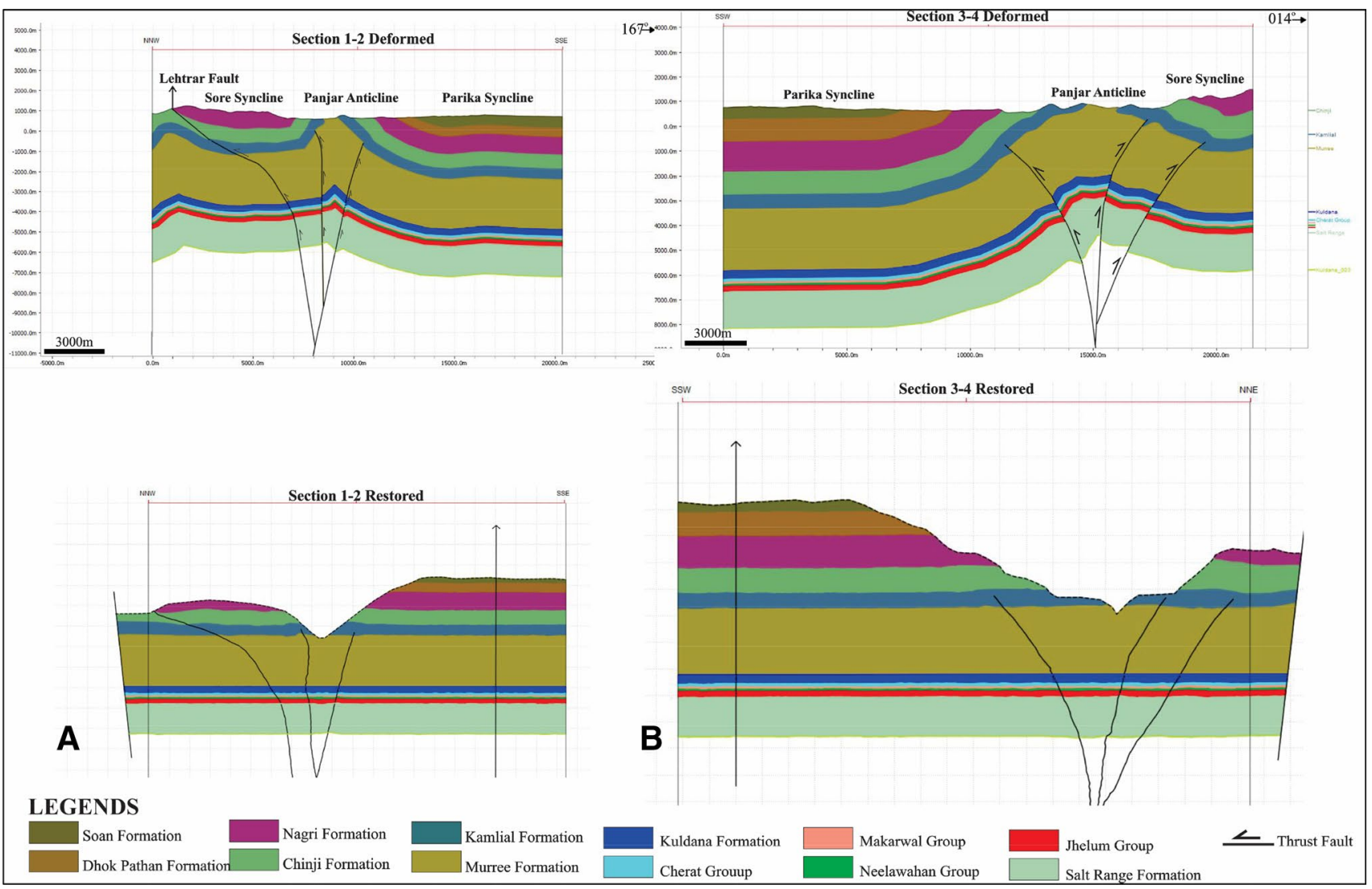

Fig. 6 Subsurface profiles of Section 1-2 and Section 3-4 showing the distribution of strata and development of positive flower structure. a \& b in the similar figure, showing the restored to its original horizontal and un-deformed state sections

the Dhok Pathan Formation outcropping in the crest of the fold. The western limb of this synclinal plunging fold is geometrically gently dipping to south-east, whereas the southern limb is steeply dipping to north-west making the fold asymmetrical by appearance. In the further east of the Nara Anticline, there is development of the Jhang Syncline, plunging in South-West direction. This result in an asymmetric fold with west side limb is gently, dipping in south-east direction and the east side limb is steeper with dips in the North-West direction (Fig. 6 $a, b)$.

\section{North-West-trending folds}

Starting from NE of the study area, the folds mapped in the eastern half includes the Chechan Anticline, the Taralla Syncline and the Baruthi Anticline". The Chechan Anticline marks the north-eastern extremity of the study area. It is an asymmetric anticlinal fold, with the Murree
Formation exposed at the surface along the hinge line. The northern limb is relatively gently dipping in the north-east direction and the southern limb is steeply dipping in the South-West direction. The Murree Formation in the core of this anticline as trending in the NW direction merges with the core of the Panjar Anticline. The following syncline in the south of the Chechan Anticline is the "Taralla Syncline", which is relatively gentle fold with the Dhok Pathan Formation in the core. The northern limb is shared with the Chechan anticline with dips in the south-west direction, and the southern limb has the dip reading of $40^{\circ} \sim 45^{\circ}$ north-east. Moving further south from the Taralla Syncline, the following anticline is the "Baruthi Anticline". The Baruthi Anticline developed in the north of the Baruthi Fault, having the Chinji Formation exposed along the crest of the fold. The northern limb is relatively steeper in the north-east quadrant, and the southern limb is dipping in the south-west direction (Fig. 7a, b). 


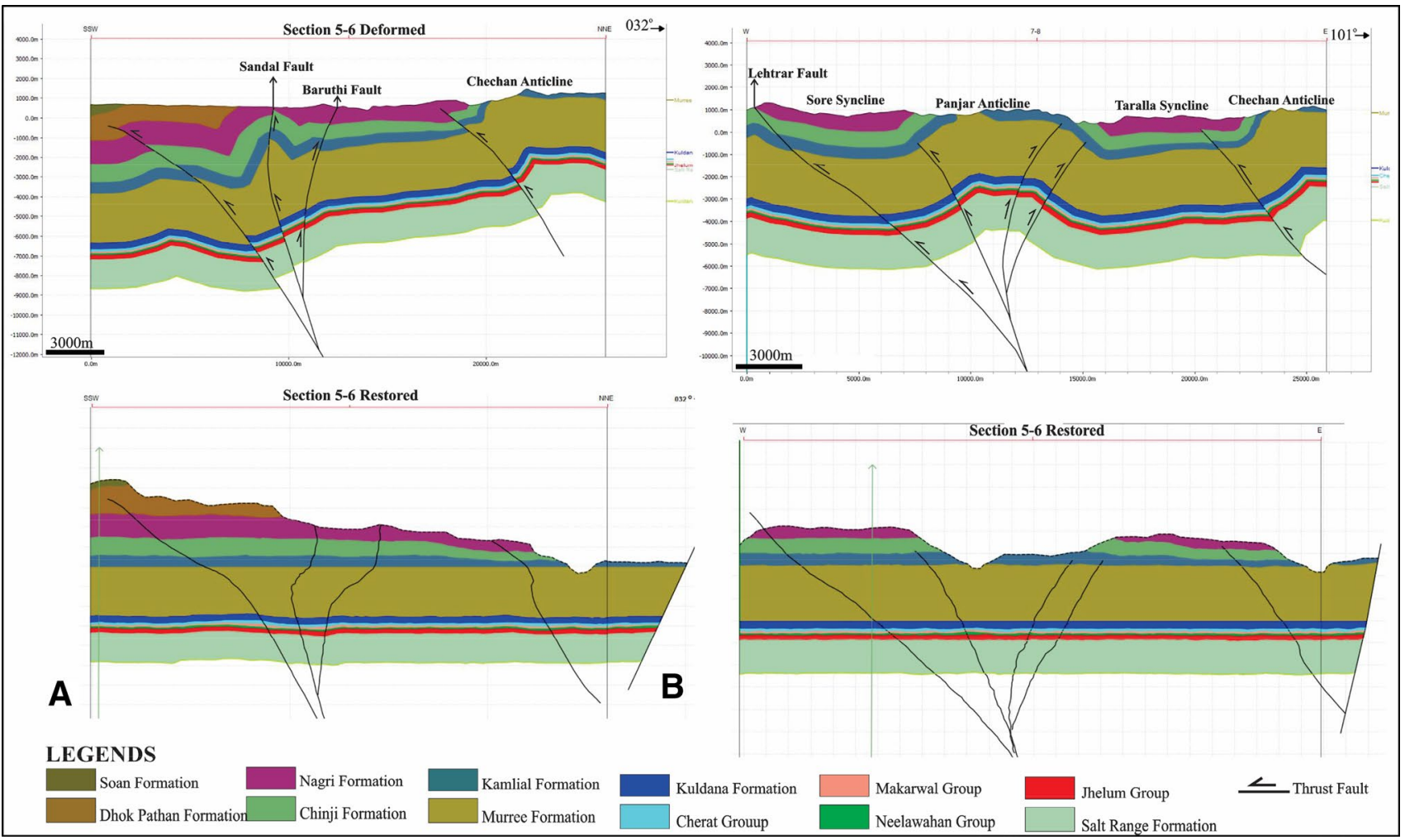

Fig. 7 Subsurface profiles of Sections 5-6 and 7-8 showing the distribution of strata and development of positive flower structure the respective $\mathrm{A}$ and $\mathrm{B}$ section of the figure showing the restored to its original horizontal and un-deformed state section

\section{Faults}

Field work was carried out to mark the Jhelum Fault. Being a strike-slip fault the feature which could be expected, there was exposure of fault plane with striations, fault gouge, echelon fractures, and stratigraphic mismatch, or when these mesoscopic structures cannot be identified, abrupt structural truncation can be used to mark the strike-slip faults. In this study, the sudden structural truncation is utilized to mark the faults (Fig. 8a, b). The faults mapped are continuous, marked as small patches and interpreted as the splays of the Jhelum Fault in the subsurface. Also being in the zone of strike-slip fault zone, all must have strike-slip component. The four faults marked in the map are the "Baruthi Fault, the Salgran Fault, the Sandal Fault and the Lehtrar Fault. The Baruthi and the Salgran faults both are marked in the Nagri Formation in the south-east of study area and hence cause the thickening of the Nagri Fault. The Baruthi Fault is marked in the south of the Baruthi Anticline. The Baruthi Fault is dipping in the south-west direction.
The Salgran Fault is marked in few kilometres west of the Baruthi Fault. The dip along the Salgran Fault marked at surface is in the south-east direction. The Salgran Fault enters study area from the south and is trending in the NE-SW direction. Both of the discussed faults merge together while striking towards the centre of study area and die out somewhere in centre of the study area. Where the Baruthi Fault terminates in the area, few kilometres south from it another fault is marked, i.e. the Sandal Fault. The Sandal Fault has strike in the SW direction and inclined towards the NE quadrant. The Sandal Fault also exposed within the Nagri Formation near contact with the Chinji Formation. The Lehtrar Fault is marked in the north-eastern corner of the study area. It is actually extended from the South-West of study area and marked at the base of the Nagri Formation. The surface trace of the Lehtrar Fault is trending in the NE, with fault plane gently dipping towards the SE, moving the entire geology in the eastern hanging wall portion of the studied area (Figs. 6 and 7 a, b). 
Fig. 8 a and $\mathbf{b}$ both are screenshots of different locations on the Google Earth, showing the presence of faults based on abrupt structural truncations
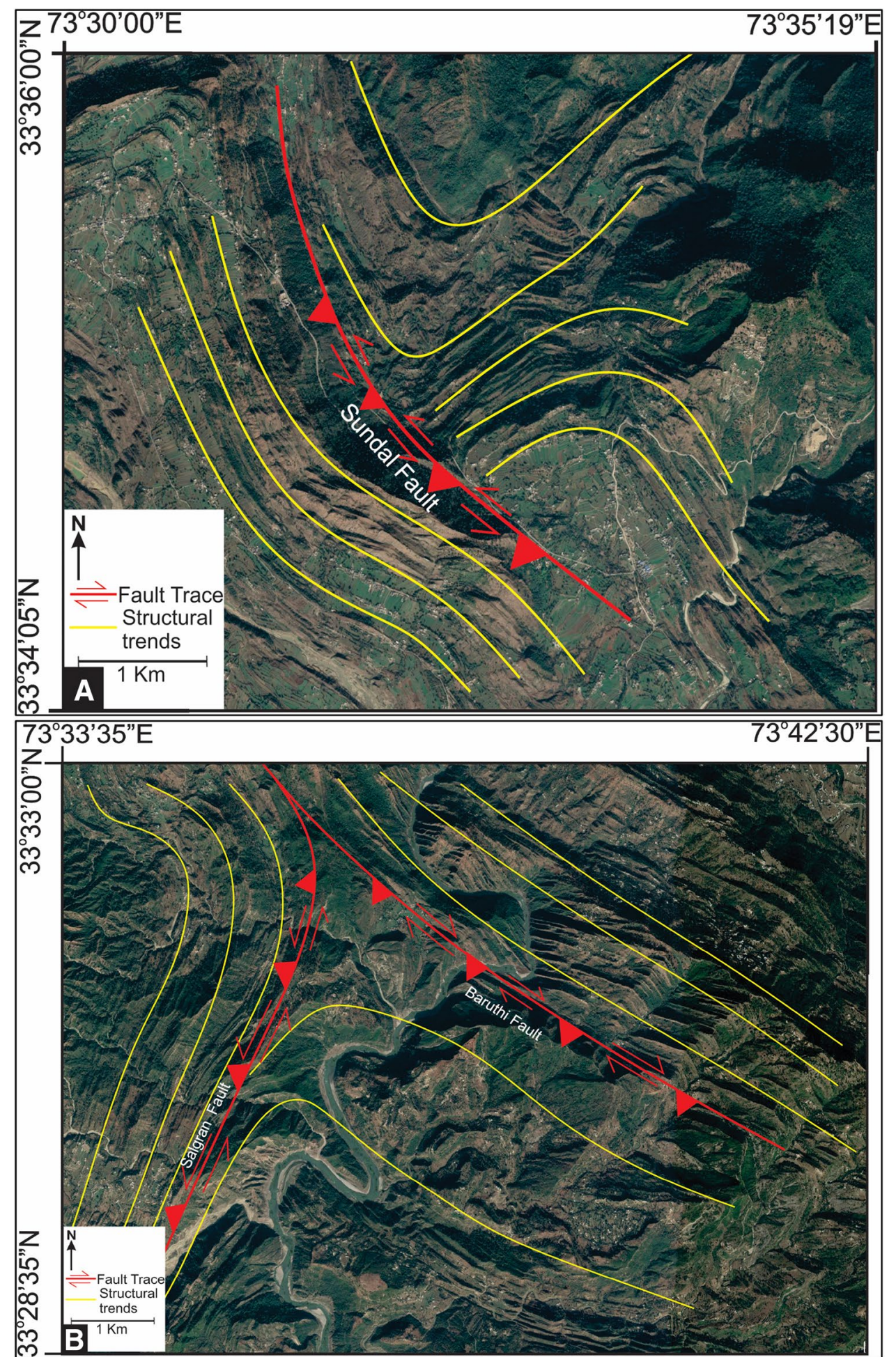

\section{Subsurface structural modelling}

Structural transects have been constructed to understand the surface and subsurface behaviour of the key structural elements along with the stratigraphic units being mapped in the study area. The subsurface modelling is based on the surface structural and stratigraphic attributes combined with the regional deformational trend and accepted 
Table 2 Showing shortening percentage along each cross section

\begin{tabular}{lcccc}
\hline $\begin{array}{l}\text { Cross Section } \\
\text { Name }\end{array}$ & Deformed Length & Restored Length & Change in Length & $\begin{array}{c}\text { Shortening } \\
\text { Percentage }\end{array}$ \\
\hline $1-2$ & $20,437.0$ & $22,140.2$ & 1703.2 & 7.69 \\
$3-4$ & $26,160.0$ & $30,380.4$ & 4220.4 & 10.89 \\
$5-6$ & $21,544.5$ & $23,650.3$ & 2105.8 & 8.90 \\
$7-8$ & $25,967.5$ & $28,730.7$ & 2763.2 & 9.61 \\
Average Shortening & & & $9.27 \%$ \\
\hline
\end{tabular}

hypothesis. The subsurface cross sections are constructed following the concept of McClay et al. 2001, where in the case of transpressional regime related to the strikeslip fault zones, there is the formation of positive flower structure in the subsurface, with little dip-slip component along each splay. Furthermore, while constructing the subsurface transects up to the deeper level, the dip of the interpreted faults is kept steeper, because all the faults are splays, accumulating shearing along broad strike-slip fault zone (Safi et al. 2021; Storti et al, 2003). Addition to the exposed stratigraphy, the subsurface horizons are correlated from the nearest well data (i.e. Kallar-X1 of PPL), which is an abandoned exploratory well drilled in 1996 in Riwat, Rawalpindi District. Four cross sections are prepared along different traverses in different directions to have maximum understanding about the structural geometry of the study area. All the cross sections are then balanced using Move Software, which utilizes the dip-isogon (lines that connect points of equal inclination or dip on the outer and inner bounding surfaces of a folded layer) while restoring the beds to their original horizontal un-deformed state. This technique of cross section balancing is done to check the validity of the subsurface interpretation. Starting from the west the first subsurface cross section, i.e. "Section 1-2" is modelled across the east-west-trending structures mapped in the area, in the NNW direction. This cross section starts from the Sore Syncline in north, terminates at the Parika Syncline in the south and runs almost perpendicular to the structural trends (Fig. 5). It explains the subsurface penetration of the surface exposed attributes along the western margin of the area. In addition to the Lehtrar Fault, which is exposed at the surface, two more faults have been modelled in the subsurface. Both of them die out while cutting the Miocene strata and are south verging, whereas the one cutting the northern limb of the Panjar Anticline is folded towards the south near the surface (Fig. 6a). This near surface folding of the fault is associated with the intensification of the transpression near the surface. The oldest strata captured on the surface along the section line are the Murree Formation, almost in the centre of the section trace. The Nagri Formation in the northern limb of the Sore Syncline marks highest peak along this cross section. The length of the cross section is $20.43 \mathrm{~km}$, with maximum exposure of the Siwalik horizons, whereas the length of the section when restored to its original horizontal un-deformed state is $22.14 \mathrm{~km}$, with shortening percentage of $7.69 \%$ (Fig. 7 a, b) (Table 2).

The second cross section from west is "Section 3-4". It also covers the eastern half of the research area, starts from the northern limb of the Panjar Anticline in the north and ends at the eastern limb of the Parika Syncline in the south. This section runs in the NNE direction and cuts obliquely the structural trends (Fig. 5). Being in the vicinity of the Section 1-2, this section also depicts the same subsurface deformation pattern. Here the dip of the faults assumed in the subsurface appears gentler as this section is cutting them obliquely (Fig. 6 a, b). The length of this cross section is $26.16 \mathrm{~km}$, which increased to $30.38 \mathrm{~km}$ when restored to uniform horizontal state. The shortening along this cross section is $10.89 \%$ (Fig. 7 $a, b)$ (Table 2). The third cross section is "Section 5-6" which covers the central portion of the mapped area. Trending in the NE direction, this section starts from the northern limb of the Chechan Anticline in the north, terminates at the Nara Anticline in the south and runs across the structures marked in the area (Fig. 5). The interpretation of subsurface deformation, in addition to the Baruthi and the Sandal Fault, another fault is modelled in the subsurface below the Chechan Anticline. All the faults are against the south verging with the little dip-slip component, whereas the fault assumed below Chechan Anticline has relatively greater dip-slip component as it rises the stratigraphic package higher in the north-eastern portion of the studied area (Fig. 7a, b). The Nagri Formation in the centre of the traverse is thickened due to the structural deformation. The Kamlial Formation in the northern limb of the Chechan Anticline marks the highest point along the section. The original length of the section is $21.54 \mathrm{~km}$, and the length of balanced un-deformed section is $23.65 \mathrm{~km}$, with shortening accumulated is $8.90 \%$ (Fig. 7) (Table 2). Section 7-8 covers the upper half of the research area across the previously 


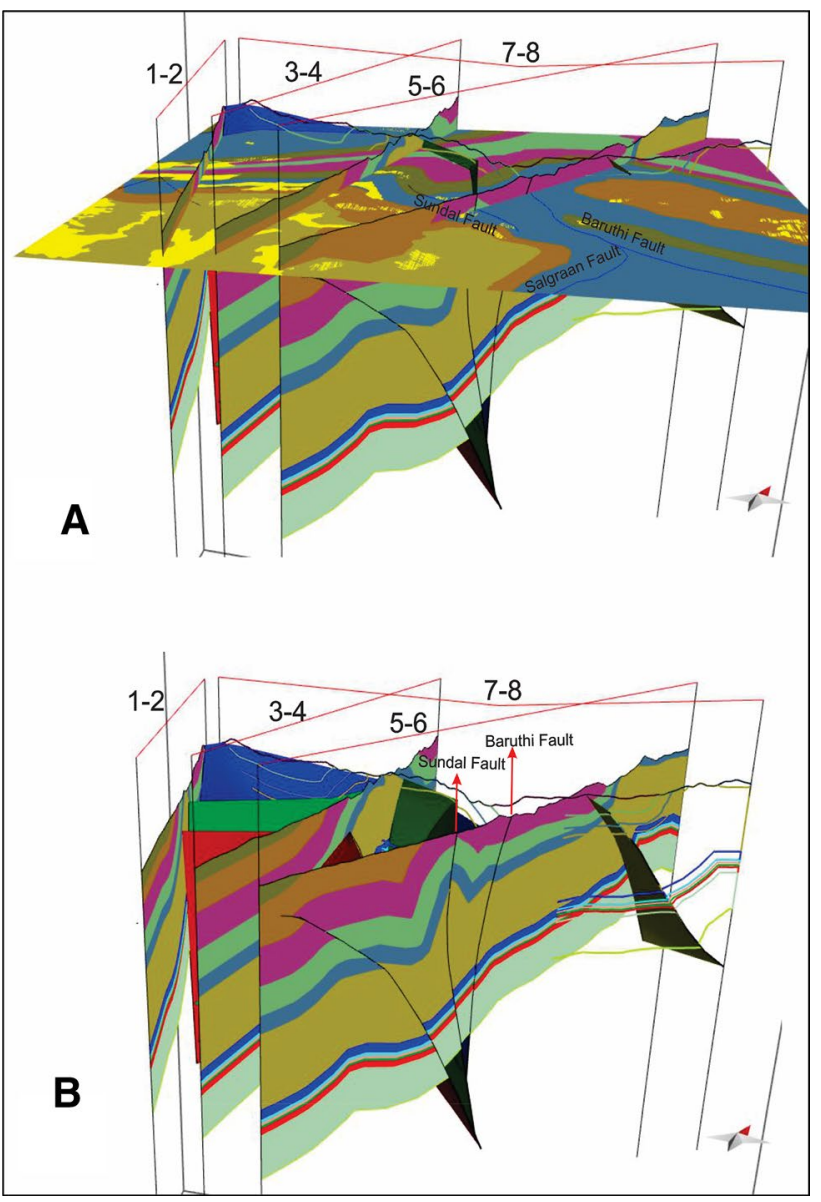

Fig. 9 a Southward 3D view showing the relation of surface deformation to subsurface model. b North-west 3D view showing vertical and lateral change in subsurface deformation

described Jhelum Fault zone; two segments of the Jhelum Fault are cutting obliquely the structures mapped in the area. In the western portion, it is trending in the NW direction, and in the eastern portion it is trending in the NE direction (Fig. 5). The length of this section is $25.96 \mathrm{~km}$ which extends to $28.73 \mathrm{~km}$ when restored, showing the shortening of $9.61 \%$ (Fig. 7 a, b) (Tab. 2). This cross section portrays the development of positive flower structure in the subsurface, along the Jhelum Fault zone (Fig. 7). The interpretation of the subsurface deformational configuration along different traverses suggests that there are several faults running in the subsurface and merge together into a single plane while penetrating deep within the crust. Some of the faults outcrops at the surface but are in the form discontinuous patches, whereas others die out within the crust along the start of terrestrial strata, i.e. Miocene fresh water sediments of

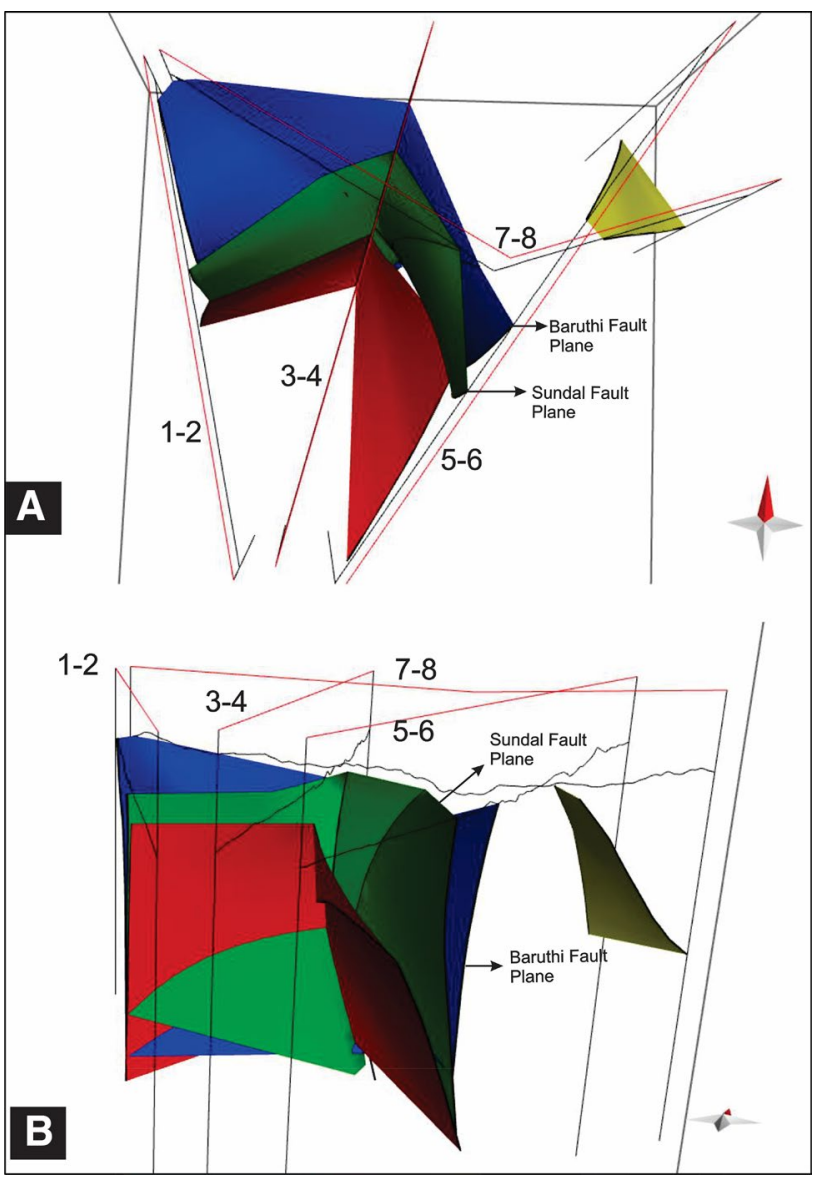

Fig. 10 a South-east 3D view showing configuration and lateral change in fault planes. b Bird eye view of 3D model showing lateral east to west change in fault planes

Rawalpindi Group. This termination of the faults below the surface exposure at the surface in the form of discontinuous traces could be accounted for the sudden change in the mechanical properties of the lithologies covering the area, i.e. fresh water sediments of Miocene age and molasse. These terrestrial deposits of Miocene and younger age are relatively less compacted, and less competent accommodates the deformation in ductile manner and resists the development of discrete break at surface. Furthermore, the stratigraphic package of the Siwalik Group has alternation of loose sandstone and shale horizons which facilitate the deformation following the flexure slip along the alternating horizons of sand and clay. The less average shortening percentage, i.e. $9.27 \%$, reflects weaker dip-slip component, which means wrenching dominates the area. 


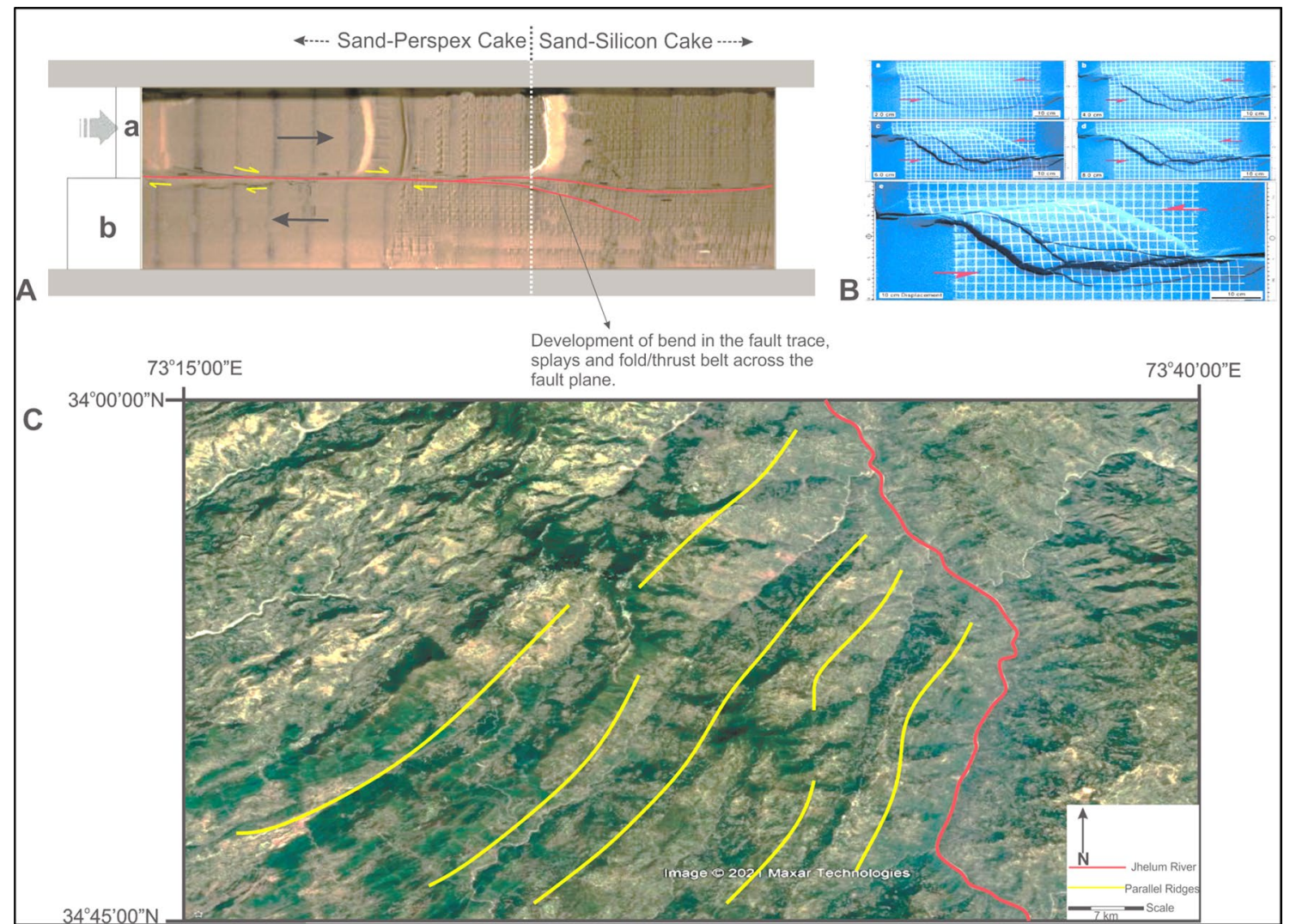

Fig. 11 a Model showing development of bent in fault plane and series of ridges on surface deformation above sand-silicon cake (From Rosas, F. M. et al. 2014). b Sequential top surface photo-

\section{D structural modelling}

Deformation in the subsurface varies laterally between adjacent cross sections (Figs. 6, 7). Therefore, for more detailed observation of subsurface deformation across 2D cross section, 3D modelling has been carried out (Figs. 9 and 10). Based on 3D modelling, it can be seen that the subsurface deformation is much complex, due to the presence of strike-slip shearing along the Jhelum Fault Zone, in addition to regional North-South collisional tectonics. The deformational geometry abruptly changes from west to east due to the shearing along the Jhelum Fault Zone (Fig. 9 a, b). Also the fault planes, which are the major structural element in controlling the surface as well as subsurface deformation, show severe northward convexity (Fig. $10 \mathrm{a}, \mathrm{b}$ ). The configuration of proposed positive flower structure also changes laterally. These flower structures leads to development of many pop-ups, which may provide structural traps for hydrocarbons accumulation (Fig. 9b). graphs, showing the development of restraining step overs c Displaying the Google Earth spot image showing the series of parallel ridges on left side of Jhelum River

\section{Discussion}

In this research, the concept of McClay et al. 2001 is adopted while constructing the subsurface cross sections, as the surface deformational pattern also reflects a bent in the fault plane of the underlying Jhelum Fault. Also the structural deformation represents transpression related to major strikeslip fault zone, which could be related to the generation of positive flower structure in the subsurface. Furthermore, while constructing the subsurface cross sections the dip of the fault planes is kept steeper as the strike-slip faults and associated splays are generally deep penetrating (Storti et al. 2003).

Rosas et al. 2014 did analogue modelling of strike-slip fault, and they found that when the strike-slip faults rupture, a sequence lying over relatively different basement in terms of elasticity, the fault trace at the surface reflects bending of the fault plane and deformation on the surface involves the development of series of ridges running parallel to one another, in the block which is experiencing 


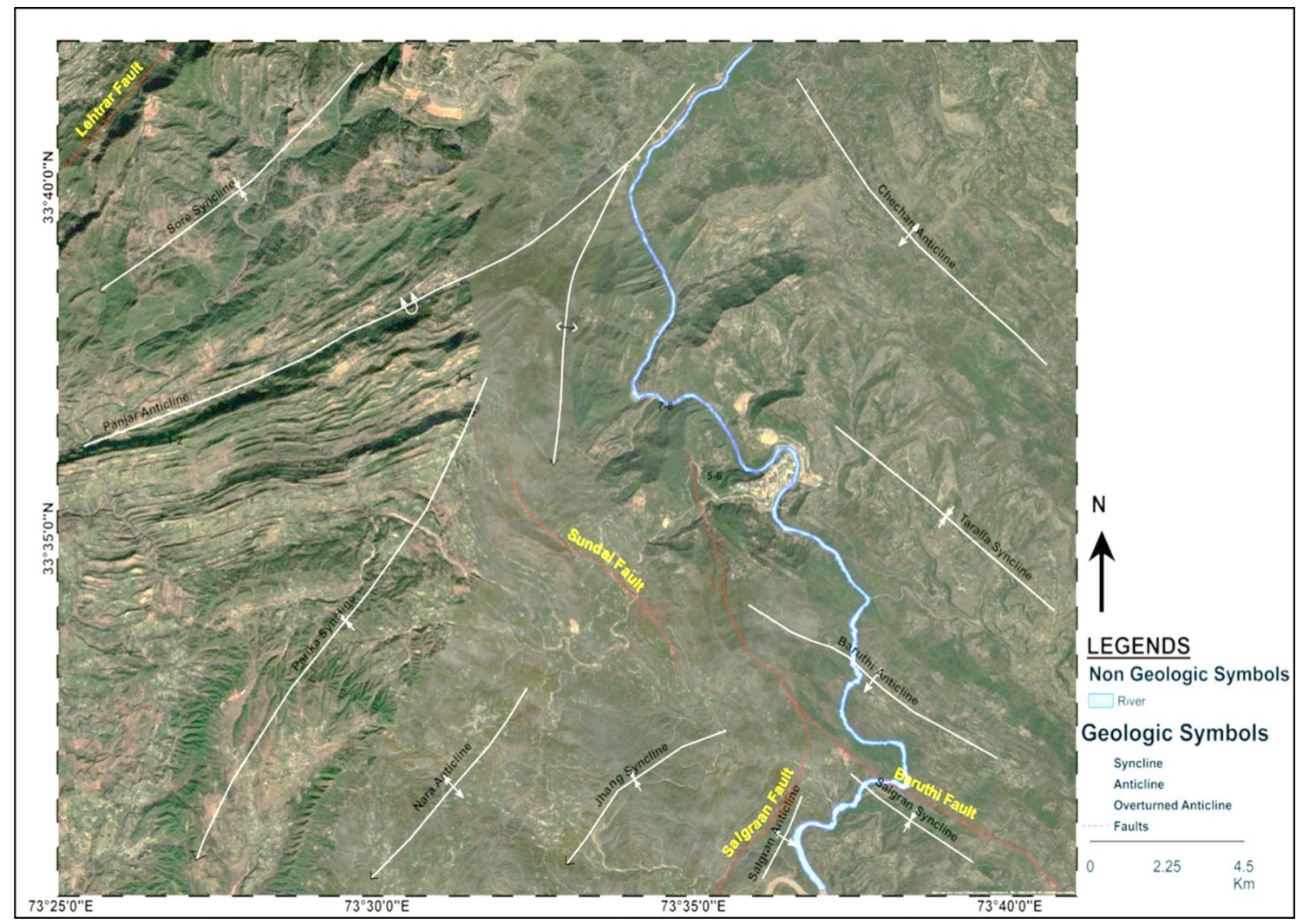

Fig. 12 Satellite image showing the two differently oriented sets of anticlines and synclines, in the eastern and western portions of the study area

compression, emerging from the main strike-slip fault (Rosas et al, 2014) (Fig. 11a). Analogue modelling of the strike-slip faults also shows that when there is bend in the fault plane of strike fault, there is development of stopovers cutting obliquely the trace of main strike-slip fault (McClay et al. 2001) (Fig. 11b). Similar topographic pattern is observed in the north of the study area, on the west side of the Jhelum River (Fig. 11c). Furthermore, the difference in the structural deformation and trends in the eastern and western sides of the study area indicates the presence of the Jhelum Fault (Fig. 12). But when the proposed area is investigated in terms of detailed geological mapping at 1:25,000 scale, it is found that the two major stresses are active in the area, i.e. the rocks are shortened in the north-south and east-west directions and no direct field evidence of continuous discrete break and dislocation is found to mark the Jhelum Fault at surface, whereas some discontinuous patches have been marked based on the sudden structural closure, which are then projected down in the subsurface while preparing cross sections. According to the sandbox analogue modelling of sinistral strike-slip faults, when there is offset of about $30^{\circ}$ in fault plane of strike-slip faults, there could be formation of thrusts cutting obliquely the associated strike-slip fault at the surface and in the subsurface there is the formation of positive flower structure (Fig. 13).

\section{Conclusion}

Based on the detailed surface and subsurface analysis of the structural deformation in the study area, it is concluded that,

- The Jhelum Fault when passes through the studied area is not exposed as a discrete continuous break of strata at surface, rather it forms a broad zone of shearing.

- While passing through the study area, it complexly deforms the rocks in a ductile way and rocks accumulate the stresses by flexure slip along layering and bedding.

- Some discontinuous faults have been marked, based on the abrupt structural truncation, which could be the surface exposure of splays along underlying Jhelum Fault.

- The subsurface cross sections also suggest that deformation along the fault zone is accumulated by splay faults from the main Jhelum Fault, which forms a positive flower structure with steep north-eastward dips, which is a characteristic of strike-slip movement along Jhelum Fault Zone. 
Fig. 13 The example of flower structure in subsurface (from the modelling of McClay and Banora, 2001), and its comparison with cross section from this research work

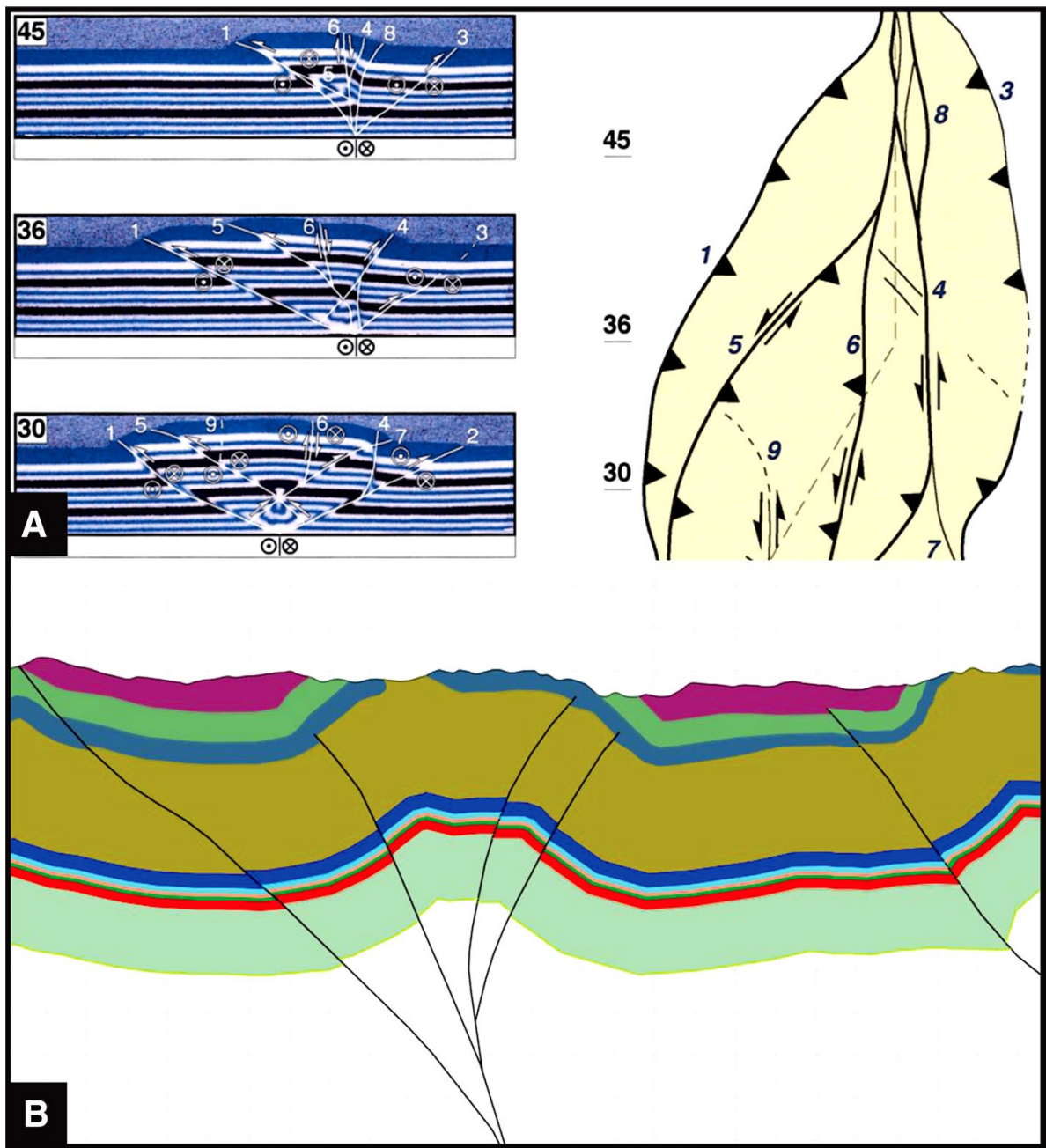

- The vertical stratigraphic throw along these faults shows small offsets and little east-west shortening, i.e. $9.27 \%$, indicating that the major slip along the fault is strike slip.

Acknowledgements The authors are grateful to Dr Sohail Wahid, Assistant Professor, NCEG and Mr. Gohar Rehman, Assistant Professor, Department of Geology University of Peshawar, for helping during field work and data interpretations. Mr. Muhammad Nouman thanks the Director, faculty, and staff of the National Centre of Excellence in Geology, University of Peshawar for providing funds for geological field work. The writers are thankful to four anonymous reviewers for the appropriate and technical suggestions for improving the manuscript. Besides, in a nutshell, we wish to express our gratitude to Editor-in-Chief Professor Dr Turgay Ertekin, PhD, for his cordial editorial support.

Funding The author(s) received no specific funding for this work.

\section{Declarations}

Conflict of interest There is no conflict of interest in the research.
Open Access This article is licensed under a Creative Commons Attribution 4.0 International License, which permits use, sharing, adaptation, distribution and reproduction in any medium or format, as long as you give appropriate credit to the original author(s) and the source, provide a link to the Creative Commons licence, and indicate if changes were made. The images or other third party material in this article are included in the article's Creative Commons licence, unless indicated otherwise in a credit line to the material. If material is not included in the article's Creative Commons licence and your intended use is not permitted by statutory regulation or exceeds the permitted use, you will need to obtain permission directly from the copyright holder. To view a copy of this licence, visit http://creativecommons.org/licenses/by/4.0/.

\section{References}

Ahmad M, Abbas, SQ, Bhattai MA, Hussain A (2004) Waliullah. geological map of plandri area, sudhnuti and kotli districts, ajk and parts of Rawalpindi district, Punjab, Pakistan (Scale 1 :50,000). Geologicl survey of Pakista, Map series, Quetta, (Sheet no: 43 G/10)

Angiolini L, Zanchi A, Zanchetta S, Nicora A, Vezzoli G (2013) The Cimmerian geopuzzle: new data from South Pamir. Terra Nova 25(5):352-360 
Baig M, Lawrence R (1987) Precambrian to early Paleozoic orogenesis in the Himalaya. Kashmir Journal of Geology 5:1-22

Baig MS, Yeats RS, Pervez S, Jadoon IA, Khan MR, Sidiqui I, Lisa M, Saleem M, Masood B, Sohail A (2010) Active tectonics, October 82005 earthquake deformation, active uplift, scarp morphology and seismic geohazards microzonation, Hazara-Kashmir Syntaxis, Northwest Himalayas. Pakistan Journal of Himalayan Earth Sciences 43:17-21

Baig M Yeats R, MonaLisa PS, Mahmood B, Sohail M, Jadoon I, Kousar A (2008) Active deformation, fault segmentation, scarp morphology, seismic hazard assessments and geohazards along Muzaffarabad Fault, Hazara Kashmir Syntaxis Northwest Himalaya Pakistan. In: International seminar "earthquake hazards pakistan: post october, 2005", Baragali Conference (22-23). National centre of excellence in geology, University of Peshawar

Dietrich VJ, Frank W, Honegger K (1983) A Jurassic-Cretaceous island arc in the Ladakh-Himalayas. J Volcanol Geoth Res 18(1-4):405-433

DiPietro JA, Pogue KR (2004) Tectonostratigraphic subdivisions of the Himalaya: a view from the west. Tectonics. https://doi.org/ 10.1029/2003TC001554

Ghani H, Zeilinger G, Sobel ER, Heidarzadeh G (2018) Structural variation within the Himalayan fold and thrust belt: a case study from the kohat-potwar fold thrust belt of Pakistan. J Struct Geol 116:34-46

Grelaud S, Sassi W, Lamotte DF, Tariq Jaswal T, Roure F (2002) Kinematics of eastern salt range and South Potwar Basin (Pakistan): a new scenario. Mar Pet Geol 19:1127-1139

Ishaq K, Wahid S, Yaseen M, Hanif M, Ali S, Ahmad J, Mehmood M (2021) Analysis of subsurface structural trend and stratigraphic architecture using 2D seismic data: a case study from Bannu Basin, Pakistan. J Pet Exploration Prod 11(3):1019-1036

Kazmi AH, Rana RA (1982) Tectonic map of Pakistan 1: 2000 000: Map showing structural features and tectonic stages in Pakistan. Geological survey of Pakistan

Le Fort P (1975) Himalayas: the collided range Present knowledge of the continental arc. American Journal of Science 275(1):1-44

McClay K, Bonora M (2001) Analog models of restraining stepovers in strike-slip fault systems. AAPG Bull 85(2):233-260

Mehdi SK Characteristics of October 08, 2005 Kashmir-hazara earthquake and its connection with Indus Kohistan Seismic Zone (IKSZ).

Pogue KR, Hussain A (1999) Geologic map of the Indus syntaxis and surrounding area. Himalaya Tibet: Mount Roots Mount Tops 328:159

Radwan A, Sen S (2021) Stress path analysis for characterization of in situ stress state and effect of reservoir depletion on present-day stress magnitudes: reservoir geomechanical modeling in the Gulf of Suez Rift Basin. Egypt Natural Resources Research 30(1):463-478

Radwan AE, Abdelghany WK, Elkhawaga MA (2021) Present-day insitu stresses in Southern Gulf of Suez, Egypt: insights for stress rotation in an extensional rift basin. J Struct Geol 147:104334

Rosas FM, Terrinha P, Duarte J, Baptista L, Kullberg C, Almeida J, Almeida P (2014) Analog modelling of strike-slip fault (lateral) propagation from an elastic to a viscous medium: insights from trial experiments. Commun Geol 101:1429-1432

Safi I, Rehman G, Yaseen M, Wahid S, Nouman M, Fida S, Anjum MN (2021) Effects of transpression on the rocks exposed at the Jhelum Fault Zone in the east of Potwar Basin, Pakistan: implications on the subsurface deformation pattern. J Pet Explor Prod Technol 11(6):2407-2424

Searle MP, Tirrul R (1991) Structural and thermal evolution of the Karakoram crust. J Geol Soc 148(1):65-82

Shah I (2009) Stratigraphy of Pakistan. Geol Surv Pakistan, Quetta 22:291-297

Storti F, Holdsworth RE, Salvini, F (2003) Intraplate strike-slip deformation belts. The geological society, London 2003. Special Publication No. 210, pp 1-14

Tapponnier P, King G, Bollinger L (2006) In: Active faulting and siesmic hazard in the western Himalayan syntaxis, Pakistan. International conference on earthquake in Pakistan. Geological Survey of Pakistan pp 2-3

Treloar PJ, Coward MP, Chambers AF, Izatt CN, Jackson KC (1992) Thrust geometries, interferences and rotations in the northwest Himalaya. Thrust tectonics, Springer, Dordrecht

Windley BF (1983) Metamorphism and tectonics of the Himalaya. J Geol Soc 140(6):849-865

Yaseen M, Naseem AA, Ahmad J, Mehmood M, Anjum MN (2021a) Integrated approach for inventories and quantitative assessment of geological and paleontological sites from precambrian to quaternary successions in the salt range Pakistan. Geoheritage 13(2): $1-24$

Yaseen M, Wahid S, Ahmad S, Rehman G, Ahmad J, Anjum MN, Mehmood M (2021b) Tectonic evolution, prospectivity and structural studies of the hanging wall of main boundary thrust along Akhurwal-Kohat transect, Khyber Pakhtunkhwa: implications for future exploration. Arab J Geosci 14(4):1-17

Zanchi A, Gaetani M (2011) The geology of the Karakoram range, Pakistan: the new 1: 100,000 geological map of Central-Western Karakoram. Italian J Geosci 130(2):161-262

Publisher's Note Springer Nature remains neutral with regard to jurisdictional claims in published maps and institutional affiliations. 